\title{
ADAPTASI DIFUSI INOVASI DALAM MEDIA EDUKASI HISTORIKAL MONUMEN TUGU MUDA SEMARANG
}

\author{
Dzuha Hening Yanuarsari, Toto Haryadi \\ Program Studi Desain Komunikasi Visual \\ Fakultas Ilmu Komputer, Universitas Dian Nuswantoro \\ dzuha.hening.yanuarsari@dsn.dinus.ac.id, toto.haryadi@dsn.dinus.ac.id
}

\begin{abstract}
Abstraksi
Bangunan-bangunan ikonik di kota Semarang menjadi saksi perjuangan masyarakat dalam melawan penjajah. Salah satunya yaitu monumen Tugu Muda sebagai simbol pertempuran lima hari Semarang. Peristiwa tersebut dikenang dalam teatrikal yang ramai ditonton oleh kalangan remaja hingga orang tua. Di sisi lain, penceritaan peristiwa bersejarah tersebut justru belum bisa dinikmati oleh anak-anak, sebagai generasi emas Indonesia. Anak-anak hanya mengetahuinya dari buku bacaan. Padahal, karakter anak dalam menyerap informasi sangat membutuhkan cara tepat diantaranya dalam empat gaya, yaitu: auditori, visual, reading, dan kinestetik. Berdasarkan permasalahan tersebut, maka dibutuhkan media edukasi yang bisa menggabungkan keempat gaya tersebut untuk memberi pengetahuan kepada anak tentang cerita historikal Tugu Muda secara efektif, komunikatif, dan menyenangkan dengan mengadaptasi teori Difusi-Inovasi berupa konsep miniatur yang ditata mengacu pada lingkungan sekitar Tugu Muda. Penelitian ini menggunakan metode kualitatif sesuai dengan permasalahan yang diangkat. Pemanfaatan konsep miniatur menjadi cara baru yang melibatkan kemampuan mendengar, melihat, membaca, serta gerak aktif anak-anak. Hasil dari penelitian ini yaitu mock up miniatur Tugu Muda yang berisi visualisasi suasana monumen beserta beberapa karakter pejuang dan penjajah, yang dikembangkan melalui design thinking.
\end{abstract}

Kata Kunci: design thinking, difusi-inovasi, edukasi, miniatur, Tugu Muda

\begin{abstract}
The iconical building in Semarang become prove about peoples struggle againts invaders. One of them is Tugu Muda as a symbol of the Semarang five days battle. That incident is remembered through theatrical which is watched by teenagers to parents. On the other side, the storytelling about that historical incident has not been enjoyed by children yet, which are Indonesia golden generation. Children know that story only from books. Whereas, children's character in obtaining information needs the right way, including in four styles, namely: auditory, visual, reading, and kinesthetic. Based on that problem, an educational media is needed to combine four styles to share knowledge for children about Tugu Muda historical story effectively, communicatively, and pleasantly by adapting Difusion-innovation theory in form of miniature concept which is arranged according to the environtment around Tugu Muda. This research uses qualitative methods according to the main problem. The usage of miniature concept becomes a new way which involves children's ability of listening, seeing, reading, and practicing. The result of this research is mock up about Tugu Muda miniature which contains visualization of the monument situation along with some characters of warrior and invader, which is developed through design thinking.
\end{abstract}

Keywords: design thinking, diffusion-innovation, education, miniature, Tugu Muda 


\section{Pendahuluan}

Berdirinya bangunan-bangunan ikonik di kota Semarang tidak terlepas dari sejarah. Bangunan ikonik yang berupa kawasan Kota Lama, Lawang Sewu, Pecinan, Pasar Johar, Tugu Muda, dan lain sebagainya menjadi saksi perjuangan masyarakat Semarang dalam melawan penjajah. Seiring waktu, beberapa bangunan tersebut ada yang mengalami kerusakan ringan hingga parah, yang dikhawatirkan hilang atau beralih fungsi menjadi bangunan modern. Bagi kalangan anak, remaja, dewasa, hingga orang tua, keindahan dan nilai sejarah dari bangunanbangunan ikonik masih bisa dinikmati secara langsung.

Tugu muda sebagai monumen yang terletak di tengah kota Semarang menjadi salah satu bangunan ikonik yang menyajikan cerita sejarah kemenangan masyarakat dalam melawan penjajah yang dikenal dengan pertempuran lima hari Semarang yang terjadi pada 14-19 Oktober 1945. Pertempuran ini merupakan perjuangan rakyat Indonesia dalam melawan penjajahan Jepang yang telah memakan korban sebanyak 850 tentara Jepang serta 2000 penduduk Indonesia, termasuk dr. Kariadi sebagai salah satu tokoh penting dalam sejarah tersebut (Utami, 2015:37). Hingga sekarang, setiap tanggal 14 Oktober diadakan drama teatrikal pertempuran lima hari Semarang yang dimulai pada tanggal 14 Oktober di kawan Tugu Muda. Upaya ini merupakan wujud upaya pemerintah dalam memperkenalkan sekaligus mengenang beratnya perjuangan para pejuang dalam mempertahankan kemerdekaan melalui pertempuran lima hari yang ditandai dengan berdirinya Tugu Muda sebagai monumen perjuangan (Salam, 2018).

Meskipun sejarah berdirinya Tugu Muda telah disajikan dengan baik dalam bentuk teatrikal, hal ini justru hanya bisa dinikmati oleh kalangan remaja, dewasa, hingga orang tua. Anak-anak sebagai generasi emas yang mewarisi sejarah ini justru belum tersentuh dan belum diprioritaskan. Padahal, pengenalan sejarah ini perlu diceritakan kepada anak-anak sejak usia dini sesuai dengan tingkat pemahamannya, baik dengan cara mendengar, membaca, hingga mempraktikkannya. Selama ini anak-anak belajar tentang sejarah pertempuran lima hari Semarang dari buku sekolah atau buku bacaan saja. Untuk menanamkan nilai-nilai sejarah yang terkandung dalam Tugu Muda kota Semarang maka dibutuhkan modalitas, yaitu cara agar informasi yang diterima panca indera bisa diserap otak secara optimal, yang terbagi ke dalam empat gaya yakni: auditori, visual, reading, dan kinestetik (Zaman dan Libertina, 2012:22). Auditori fokus pada kemampuan anak dalam menerima informasi dengan cara mendengar. Gaya visual fokus pada kemampuan anak dalam melihat bentuk-bentuk gambar. Reading fokus pada kemampuan anak dalam membaca informasi dalam bentuk tulisan. Sedangkan kinestetik fokus pada kemampuan psikomotorik atau praktik anak.

Berdasarkan karakteristik cara anak dalam menerima informasi khususnya tentang nilai-nilai historikal monumen Tugu Muda Semarang, maka diperlukan strategi penyampaian yang tidak hanya komunikatif tetapi juga kreatif dan inovatif, salah satunya melalui strategi difusi-inovasi. Menurut Roger dalam Meita (Haryadi, 2017:2), difusi-inovasi merupakan proses 
komunikasi dalam menyampaikan sebuah inovasi atau hal baru melalui media tertentu yang ditujukan kepada masyarakat melalui tahapan-tahapan tertentu. Dari permasalahan tersebut di atas, maka penelitian ini fokus pada bagaimana mengadaptasi teori Difusi-Inovasi dalam media edukasi historikal monumen Tugu Muda Semarang?

\section{Tinjauan Teori}

\section{a. TUGU MUDA}

Tugu Muda merupakan monumen di kota Semarang yang didirikan untuk mengenang sejarah pertempuran lima hari melawan penjajahan Jepang. Secara fisik, Tugu Muda berbentuk obbor dengan tinggi mencapai 53 meter, yang menjadi simbol semangat perjuangan warga Semarang yang terus menyala. Tugu Muda terdiri dari tiga bagian yaitu: lima pilar kaki, tubuh, dan kepala. Khususnya di bagian pilar berisi relierelief yang menceritakan kisah berurutan, dimulai dari pilar pertama tentang penderitaan rakyat akibat dijajah; pilar kedua tentang pertempuran menggunakan bambu runcing; pilar ketiga tentang penyerangan markas-markas Jepang; pliar keempat tentang korban jasad yang bergelimpangan; serta pilar kelima tentang kemenangan warga Semarang (Herawati, 2016).

\section{Gambar 1. Tugu Muda}

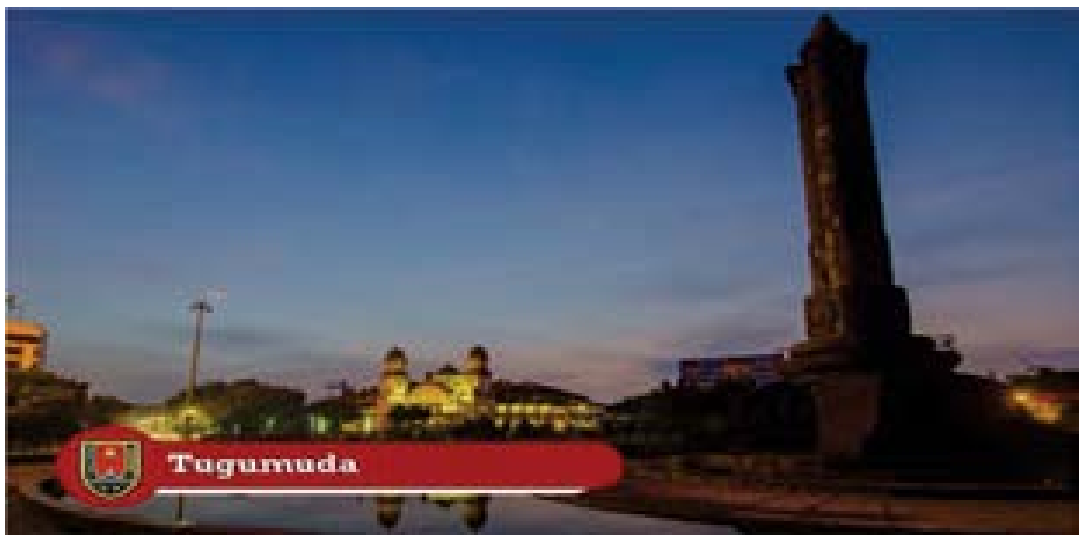

Sumber: https://semarangkota.go.id/galeri/foto/13?page=1

Cerita pertempuran lima hari di Semarang terjadi pada tanggal 15 - 20 Oktober 1945, yang bermula dari bentrokan antara polisi Indonesia dengan tentara Jepang. Salah satu klimaks dari pertempuran lima hari yaitu upaya curang tentara Jepang saat meracuni cadangan air yang terletak di kawasan Candi. Kecurangan tersebut berdampak pada ditembaknya dr. Kariadi oleh tentara Jepang saat memeriksa cadangan air tersebut. Kematian dr. Kariadi menimbulkan kemarahan besar bagi warga Semarang, sehingga 
pertempuran menjadi sengit dan menimbulkan banyak korban baik di pihak pejuang maupun pihak penjajah. Dari peristiwa tersebut dibuatlah monumen Tugu Muda Semarang (Komandoko, 2010:54).

\section{b. DIFUSI - INOVASI}

Diantara banyak teori komunikasi, Difusi-inovasi menjadi pilihan utama dalam penelitian ini. Teori ini diperkenalkan oleh Everret M. Roger pada tahun 1962 yang menjelaskan pengenalan dan adaptasi sebuah inovasi oleh suatu komunitas. Difusi-inovasi fokus pada sosialisasi ide-ide yang bersifat baru. Difusi secra harfiah berarti penyebaran dari satu pihak ke pihak lainnya, bisa berupa kebudayaan, teknologi, maupun ide (KBBI, 2008:353). Inovasi mengarah pada pembaharuan terhadap sebuah hal (KBBI, 2008:557). Difusi-inovasi fokus pada bagaimana menyebarkan sebuah pembaharuan baik berupa kebudayaan, teknologi, atapun ide dari satu pihak kepada pihak lain melalui tahapan yang telah ditentukan.

Penyampaian informasi melalui Difusi-inovasi diawali dari media, sebagaimana dijelaskan Rogers dan Shoemaker (Antoni, 2004:116) bahwa media berperan penting dalam promosi difusi dan adopsi terhadap inovasi. Hal ini juga dijelaskan Roger (Santoso, 2014:394) bahwa media menjadi sesuatu yang inovatif dan diadaptasi oleh adopter awal (sekelompok kecil orang), kemudian dipelajari oleh opinion leader dan dipertimbangkan aspek kegunaan dan mengajak orang lain untuk mengadaptasinya. Secara lebih jelasnya, proses Difusi-inovasi terdiri dari empat tahapan menurut Rogers dan Shoemaker (Daryanto, 2014:136), sebagaimana tercantum pada gambar berikut:

\section{Gambar 1. Konsep Difusi Inovasi}

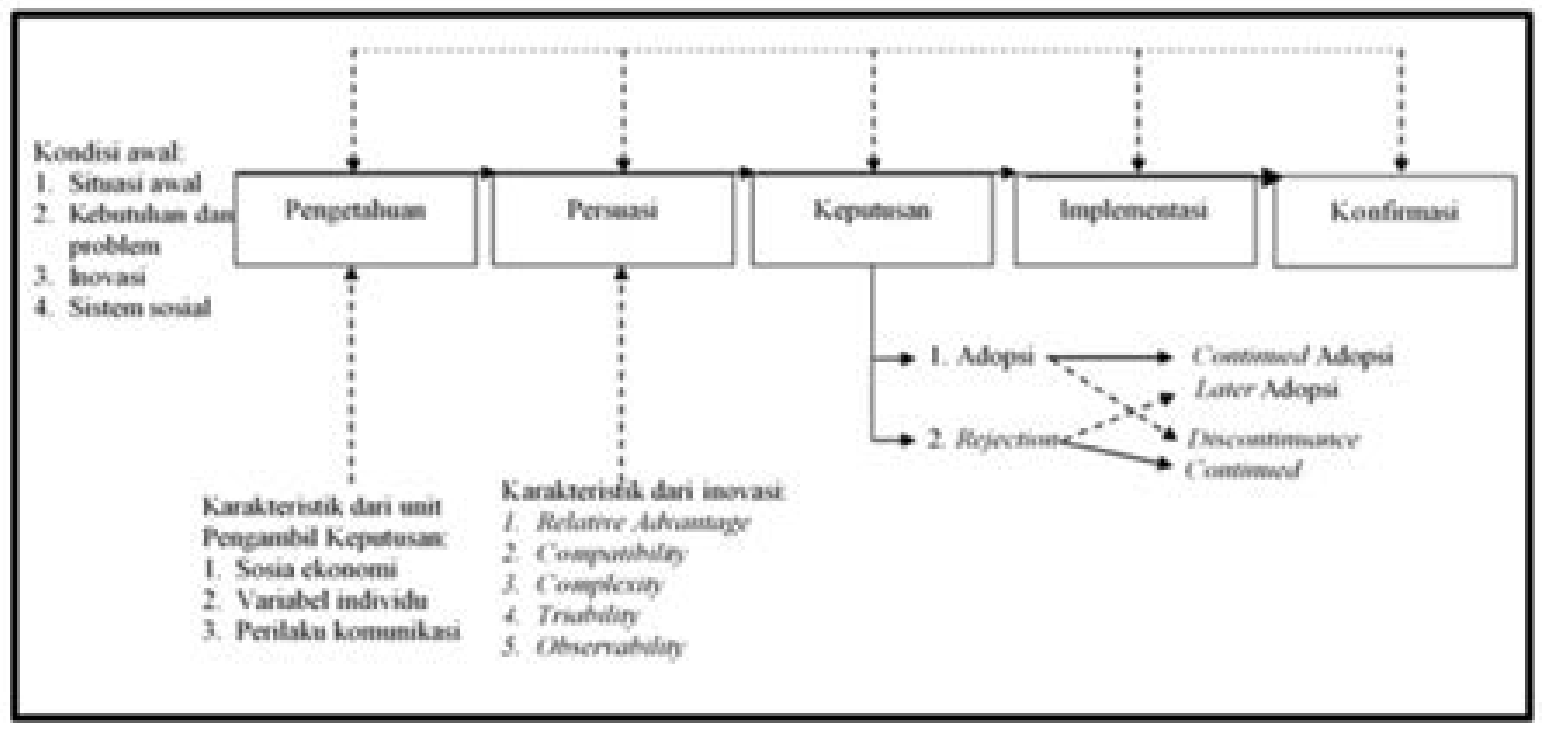

Sumber: Rekonstruksi Rogers (1983) 
Pada tahap awal, kesadaran individu terhadap adanya inovasi beserta fungsinya menjadin poin penting (Pengetahuan). Hal ini menentukan sikap individu dalam menerima atau tidak inovasi yang ditawarkan (Persuasi). Individu memiliki peran penting dalam menentukan pilihan untuk mengadopsi atau menolak inovasi yang ditawarkan (Keputusan). Individu juga memiliki kesempatan untuk mencari pendapat yang menguatkan keputusan yang telah diambilnya dan bersifat fleksibel (Konfirmasi).

\section{c. DESIGN THINKING}

Design Thinking merupakan sebuah metode tindakan kreatif yang dipopulerkan oleh Rolf Faste tahun 1980. Design thinking berhubungan dengan peluang yang dilatarbelakangi oleh problem/masalah di sekitar. Design thinking merupakan metode yang fokus pada proses menciptakan ide-ide baru dan inovatif untuk memecahkan masalah. Design thinking membantu proses analisis masalah untuk menemukan solusi, sehingga metode ini tidak fokus pada permasalahan yang ada, tetapi fokus pada penemuan solusi dari masalah yang ada (Radianto dkk, 2018:162-163).

Awalnya metode ini lebih sering digunakan dalam bidang entrepreneurship (bisnis). Pada perkembangannya teori ini lebih luas penggunaannya, contohnya pada bidang desain dan pendidikan. Design thinking bersifat formal namun praktis, sebagai cara pencarian solusi yang kreatif dari masalah atau isu dengan tujuan untuk mendapatkan hasil yang lebih baik ke depannya. Design thinking juga mengaktualisasi ide dan konsep, yang terdiri dari lima tahapan, yaitu: Empathize, Define, Ideate, Prototype, dan Test (Ramdhan, 2016:36-37).

\section{Gambar 2. Tahapan Design thinking}

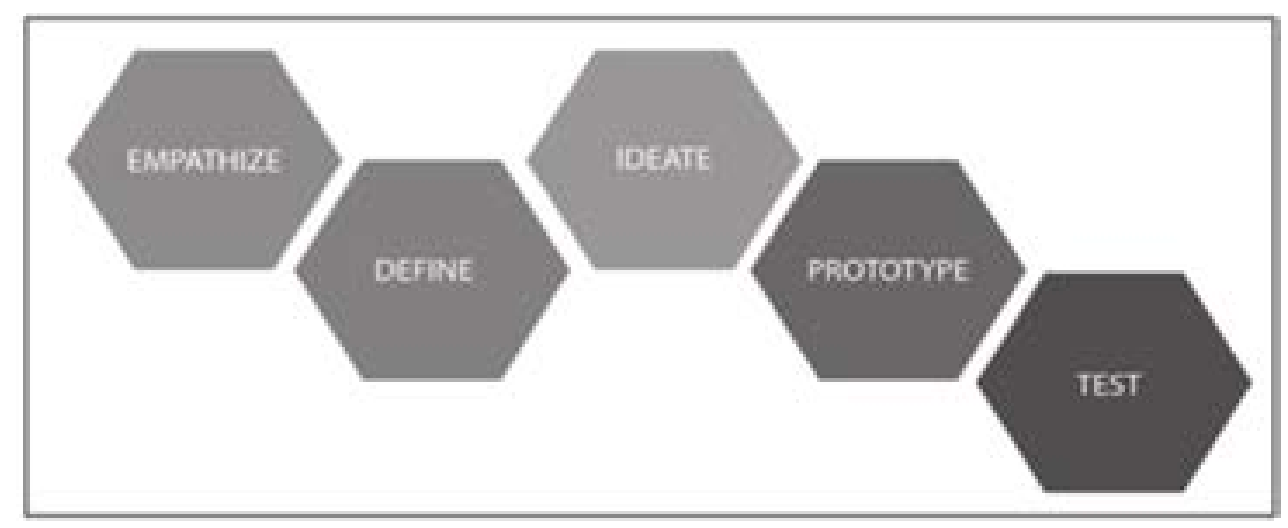

Sumber: Ramdhan (2016: 37)

Tahap empathize fokus pada pemahaman mendalam tentang masalah yang akan diselesaikan untuk mengesampingkan asumsi yang tidak diperlukan. Pada tahap define, 
informasi yang telah diperoleh digunakan untuk mendefinisikan masalah utama dalam bentuk problem statement. Pengembangan ide ada pada tahap ideate, fokus pada pencarian alternatif-alternatif pemecahan masalah yang salah satunya bisa dilakukan dengan brainstorming. Dari banyak ide yang ada, satu ide terbaik akan dikembangkan menjadi prototype sebagai wujud implementasi solusi dan bersifat eksperimental. Tahapan terakhir yaitu test, pengujian prototype atau solusi yang telah dihasilkan untuk mendapatkan saran/masukan dari orang lain.

\section{Metode Penelitian}

Penelitian ini menggunakan metode deskriptif kualitatif sesuai dengan permasalahan yang diangkat yaitu belum adanya cara dan media yang sesuai untuk memberikan materi edukasi seputar historikal monumen Tugu Muda Semarang, yang akan ditujukan pada anakanak. Melalui metode ini didapatkan paparan deskriptif baik verbal maupun visual tentang konsep adaptasi teori Difusi-Inovasi yang didukung dengan metode design thinking. Pemilihan teori dan metode ini didasarkan pada kesamaan tujuan yang diharapkan, yaitu menciptakan solusi secara kreatif dan inovatif dengan mengutamakan khalayak. Langkah awal yang dilakukan yaitu membandingkan media-media yang pernah ada untuk tujuan yang sama. Perbandingan akan menghasilkan konsep media edukasi yang diusulkan dikembangkan dengan tahapan disign thinking, dan hasil akhir baik dalam bentuk prototype atau mock up dikorespondensikan dengan Difusi-inovasi dan diusulkan sebagai cara baru dalam menanamkan edukasi historikal monumen Tugu Muda Semarang.

\section{Hasil dan Pembahasan}

\section{a. Perbandingan Karya Bertema Sama}

Karya bertema sama yang akan dibandingkan ada dua macam, yaitu: game dan buku ilustrasi. Keduanya memiliki tema sama yaitu cagar budaya kota Semarang. Keduanya juga merupakan karya hasil penelitian penulis pertama, sebagai sosialisasi peninggalan sejarah dan edukasi budaya. Aspek-aspek yang digunakan untuk perbandingan di sini yaitu: media publikasi, konten karya, cara penyajian konten, target pengguna, kelebihan karya, kelemahan karya, serta kecocokan untuk usia anak-anak. Hasil perbandingan akan digunakan untuk mengusulkan media baru yang sesuai dengan karakteristik anak-anak sebagai target pengguna. Berikut perbandingan dua karya yang telah disebutkan di atas. 
Tabel 1. Perbandingan dua karya bertema cagar budaya

\begin{tabular}{|c|c|c|}
\hline Karya & Game Cagar Budaya & $\begin{array}{l}\text { Buku Ilustrasi } \\
\text { Cagar Budaya }\end{array}$ \\
\hline Media publikasi & $\begin{array}{c}\text { Game komputer action } \\
\text { adventure }\end{array}$ & Buku ilustrasi \\
\hline Konten karya & $\begin{array}{l}\text { Penggambaran suasana La- } \\
\text { wang Sewu era peperangan }\end{array}$ & $\begin{array}{l}\text { Tampilan bangunan masjid } \\
\text { Kauman, Lawang Sewu, } \\
\text { Stasiun Tawang, Sam Poo } \\
\text { Kong, dan gereja Blenduk }\end{array}$ \\
\hline Cara penyajian konten & $\begin{array}{l}\text { Disimulasikan sebagai } \\
\text { cerita utama dan environ- } \\
\text { ment (latar) dalam game }\end{array}$ & $\begin{array}{c}\text { Disajikan tiap } 1 \text { sisi } \\
\text { halaman penuh dengan } \\
\text { deskripsi (keterangan } \\
\text { bangunan) di sisi halaman } \\
\text { satunya }\end{array}$ \\
\hline Target pengguna & Anak-anak & $\begin{array}{c}\text { Anak-anak (siswa sekolah } \\
\text { dasar) }\end{array}$ \\
\hline $\begin{array}{c}\text { Manfaat yang bisa diper- } \\
\text { oleh }\end{array}$ & $\begin{array}{l}\text { Pengetahuan tentang ben- } \\
\text { tuk bangunan dan cerita } \\
\text { sejarah Lawang Sewu; } \\
\text { kemampuan psikomotorik } \\
\text { anak }\end{array}$ & $\begin{array}{l}\text { Pengetahuan gambar visual } \\
\text { bangunan-bangunan cagar } \\
\text { budaya beserta deskrip- } \\
\text { sinya, kemampaun kognitif } \\
\text { dan afektif anak }\end{array}$ \\
\hline Kelebihan karya & $\begin{array}{c}\text { Bersifat fun, interaktif, ko- } \\
\text { munikasi } 2 \text { arah, tindakan } \\
\text { aktif }\end{array}$ & $\begin{array}{l}\text { Informasi lengkap (gam- } \\
\text { bar dan teks), berpotensi } \\
\text { didampingi orang tua/guru, } \\
\text { mudah dipahami, menum- } \\
\text { buhkan minat membaca } \\
\text { dan bercerita anak }\end{array}$ \\
\hline Kekurangan karya & $\begin{array}{c}\text { Interaksi bersifat vir- } \\
\text { tual (anak dengan game), } \\
\text { mengesampingkan } \\
\text { pendampingan orang tua, } \\
\text { berpotensi membuat ke- } \\
\text { canduan, fokus anak lebih } \\
\text { ke permainannya dibanding } \\
\text { kandungan ceritanya }\end{array}$ & $\begin{array}{c}\text { Anak cenderung pasif, ko- } \\
\text { munikasi hanya satu arah, } \\
\text { tidak interaktif, membuat } \\
\text { bosan }\end{array}$ \\
\hline
\end{tabular}




\begin{tabular}{|c|c|c|}
\hline $\begin{array}{c}\text { Kesesuaian untuk usia anak- } \\
\text { anak }\end{array}$ & $\begin{array}{c}\text { Tidak sesuai, lebih banyak } \\
\text { kerugian dibanding man- } \\
\text { faat yang akan diperoleh }\end{array}$ & $\begin{array}{c}\text { Cukup sesuai, tetapi butuh } \\
\text { peran aktif orang tua/guru } \\
\text { sebagai pendamping serta } \\
\text { mendorong anak untuk ikut } \\
\text { aktif }\end{array}$ \\
\hline
\end{tabular}

Dari tabel perbandingan game dan buku ilustrasi di atas, bisa disimpulkan bahwa media edukasi yang akan dirancang harus memiliki kelebihan yang ada di kedua media yang telah ada sebelumnya serta sebisa mungkin hanya memiliki sedikit kekurangan. Aspek yang harus ada dalam media yang diusulkan yaitu adanya interaksi dua arah antara anak dengan pendamping, menstimulasi anak bersifat aktif dan bermain peran, memiliki tampilan menarik dan menyenangkan, serta mudah dipahami. Salah satu media yang cocok dengan kriteria di atas yaitu miniatur monumen bangunan Tugu Muda dan Lawang Sewu yang memiliki keterkaitan historikal.

\section{b. Pengembangan Mock Up Miniatur melalui Design Thinking}

Design thinking diperlukan untuk merumuskan konsep miniatur yang akan dibuat sesuai dengan kriteria yang dijelaskan di atas. Pada tahap Empathize, permasalahan utama terletak pada belum sesuainya cara dan media yang ada sebagai sarana edukasi historikal monumen Tugu Muda. Pada tahap define, statement pokok yang diperoleh yaitu "Kolaborasi anak, pendamping, dan media dalam mengenal historikal monumen Tugu Muda". Statement tersebut muncul didasarkan pada keadaan yang mendorong terciptanya hubungan kedekatan antara orang tua/guru dengan anak dalam mengenalkan sejarah cagar budaya dengan mengajak anak berperan aktif. Pada tahap ideate, salah satu alternatif solusi yang ditawarkan yaitu sebagaimana telah dijelaskan di atas, yakni merancang miniatur monumen bangunan Tugu Muda dan Lawang Sewu dalam bentuk mock up. Secara lebih detail, untuk mengeksplorasi empat gaya belajar anak secara terpadu yakni: mendengar - melihat - membaca - bertindak, maka miniatur dikonsep menjadi medium yang bisa membangun hubungan aktif antara pendamping dan anak, sehingga pendamping bisa berperan membangun cerita, dan anak bisa menangkap serta memperagakan cerita melalui miniatur.

Pada tahap prototype, miniatur yang digagas peneliti yaitu menggambarkan latar atau situasi Tugu Muda dan Lawang Sewu era pertempuran lima hari Semarang. Kedua bangunan tersebut menjadi latar belakang (background/environment), dan untuk menyajikan media edukasi yang hidup, ditambahkan model karakter pejuang kemerdekaan, prajurit musuh (penjajah), serta kendaraan perang yang bisa dipindah-pindah dan digerakkan dengan tangan sesuai dengan narasi/cerita yang disajikan. Berikut visualisasi miniatur mulai dari 
penggambaran objek hingga konsep penataan aset miniatur meliputi latar dan karakter yang bisa digerakkan.

\section{Gambar 3. Visualisasi Tugu Muda dan Lawang Sewu sebagai latar}

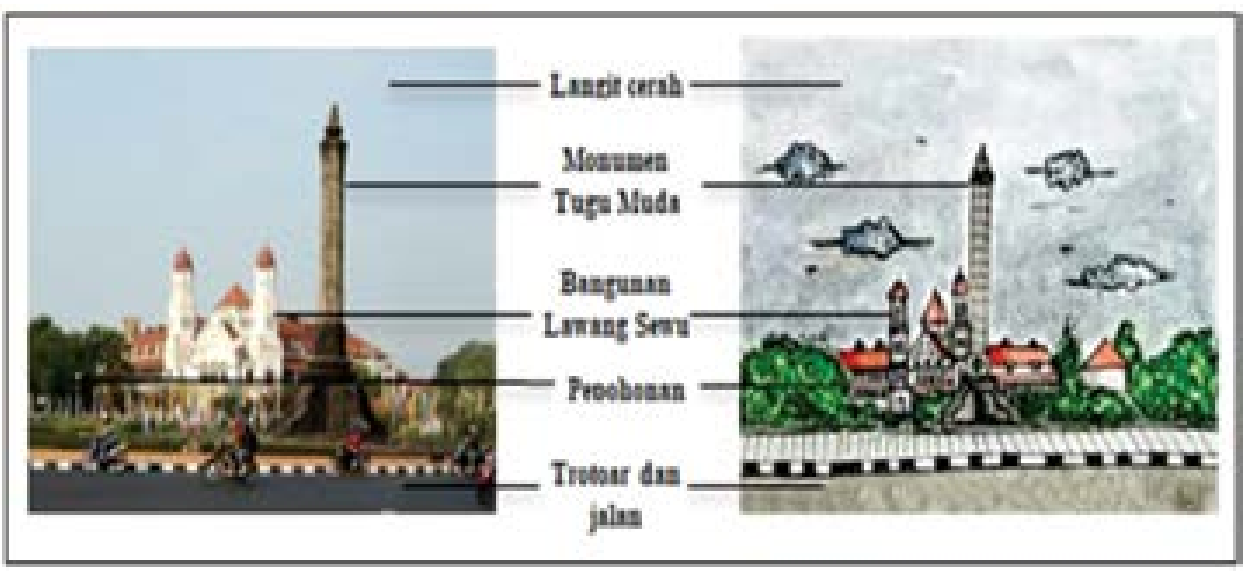

Gambar 4. Visualisasi karakter pejuang dan penjajah

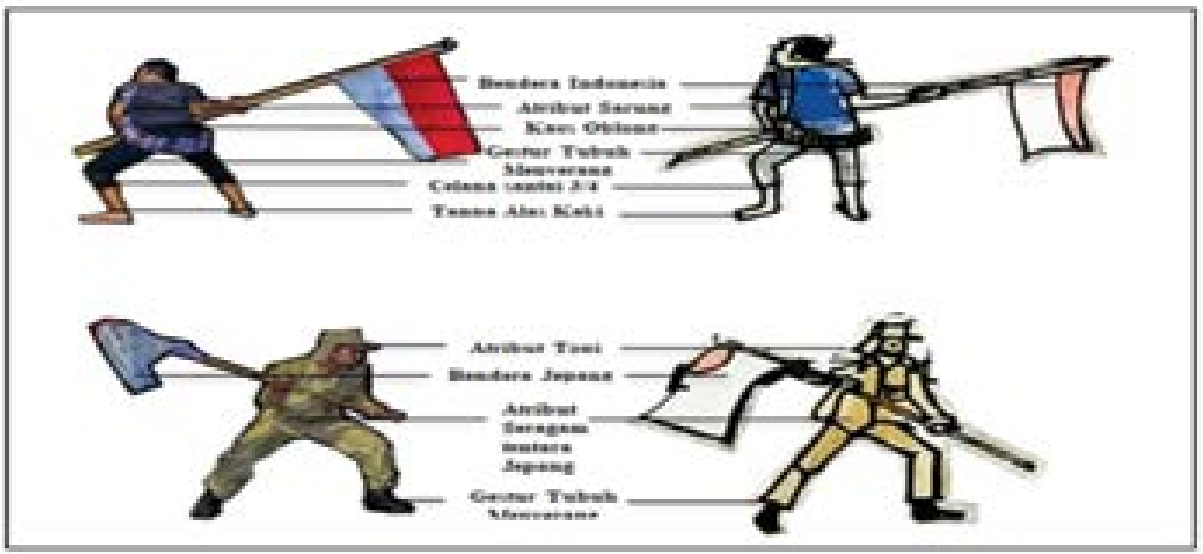

Gambar 5. Visualisasi mock up penempatan latar

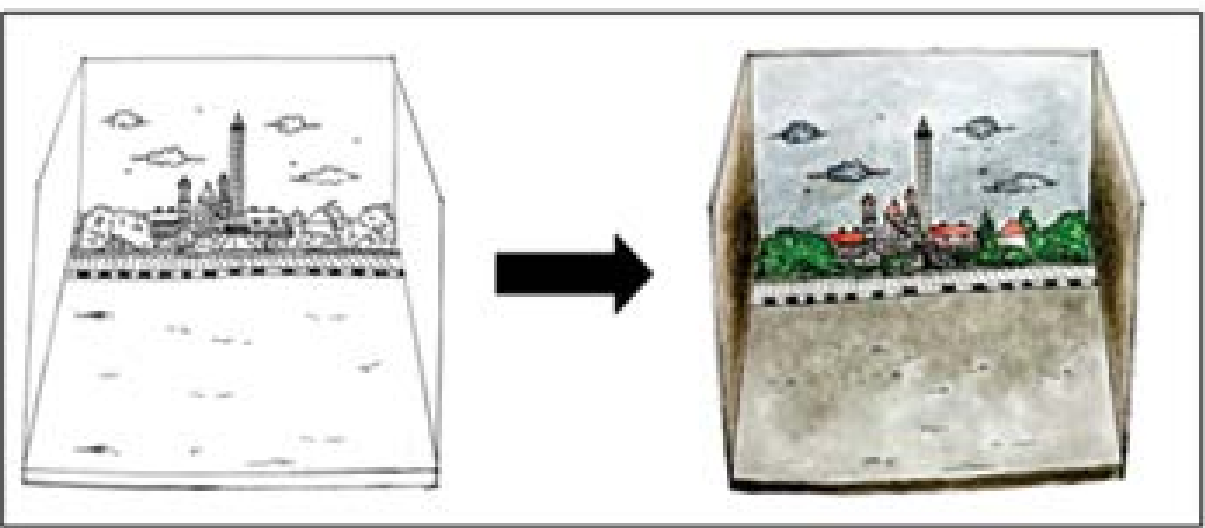


Gambar 6. Visualisasi mock up penataan konten miniatur

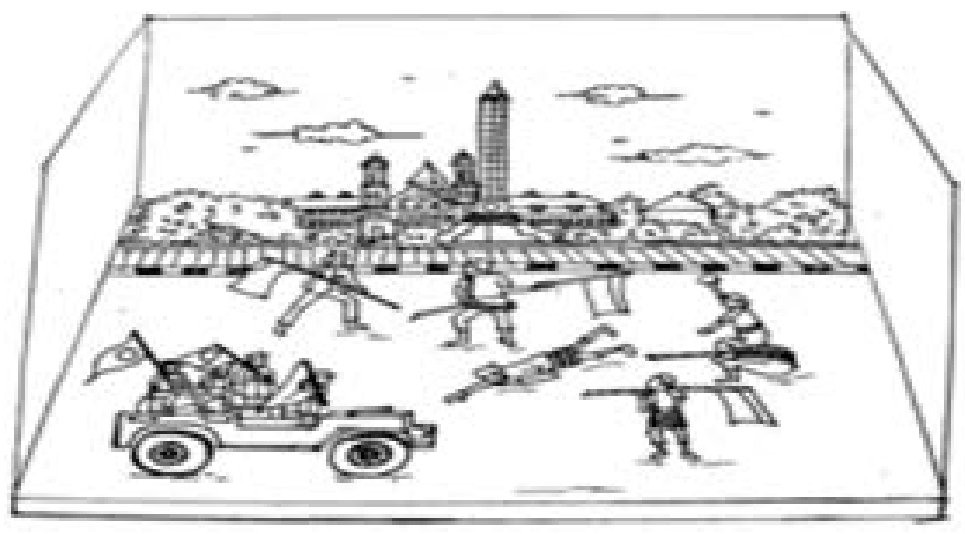

Gambar 7. Visualisasi mock up miniatur monumen Tugu Muda dan Lawang Sewu

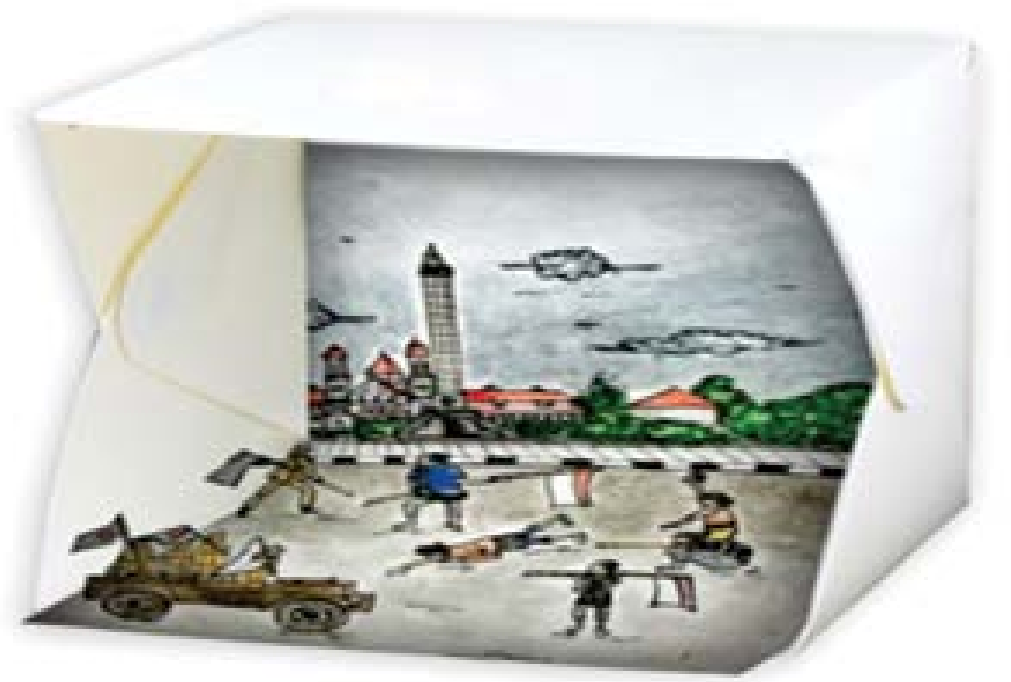

Secara umum, mock up miniatur di atas digambar dengan gaya realis-simplifikasi, yaitu penyederhanaan namun mempertahankan kemiripan dengan objek aslinya. Secara bahasa rupa, penataan semua asetnya menggunakan layering foreground-background (depan belakang), yaitu penataan objek sesuai orientasinya yang ingin ditonjolkan. Latar berupa Tugu Muda dan Lawang Sewu ditempatkan paling belakang karena bersifat statis. Karakter pejuang dan penjajah ditempatkan di depan latar, yang bisa digerakkan dan ditempatkan secara bebas di area miniatur. Mobil ditempatkan di depan kedua karakter, menjadi elemen pendukung untuk mendramatisasi cerita. Penataan yang dilakukan sedemikian rupa dimaksudkan untuk memberi kesan "semakin dekat dengan mata maka objek semakin besar dan bersifat penting". Konsep penataan semacam ini juga memberi persepsi kedalaman (3 dimensi), meskipun semua aset digambar dalam bentuk dua dimensi. Sehingga, miniatur ini mirip dengan konsep penataan panggung teatrikal. 
Berdasarkan sudut lihat mata, miniatur ini dinikmati dengan posisi bird view, yaitu melihat dari sisi atas secara isometris. Tujuannya yaitu agar mata bisa melihat miniatur secara keseluruhan secara lebih detail dibanding melihat dengan sudut sejajar mata yang hanya fokus pada objek yang letaknya paling depan. Setiap objek dibuat dengan skala lebih kecil dari asli, dengan proporsi yang tepat sehingga komposisi penataan miniatur terasa pas perbandingannya. Adanya frame atau box menjadi batas ukuran miniatur yang dimaksudkan agar cerita yang disajikan sesuai porsi yaitu tentang pertempuran lima hari Semarang yang terjadi di kawasan Tugu Muda dan Lawang Sewu.

Setelah prototype berhasil dirancang, tahapan berikutnya yaitu test. Miniatur yang telah dirancang sesuai konsep perlu diujikan kepada target sasaran, yaitu anakanak. Respon yang didapat dari target sasaran dijadikan sebagai bahan masukan untuk menyempurnakan miniatur agar sesuai dengan tujuan yang ingin dicapai yaitu sebagai media edukasi historikal monumen Tugu Muda Semarang.

\section{c. Implementasi Miniatur dalam Teori Disfusi InovasilFUSI-INOVASI}

Perancangan miniatur melalui Design thinking telah dijabarkan dengan jelas. Proses berikutnya yaitu penjabaran adaptasi Difusi-inovasi mock up miniatur sebagai media edukasi historikal monumen Tugu Muda. Berikut konsep implementasi mock up miniatur dalam Difusi-inovasi mulai dari tahap Pengetahuan hingga tahap Konfirmasi.

\section{Gambar 8. Konsep adaptasi Difusi-Inovasi dalam mminiatur Tugu Muda}

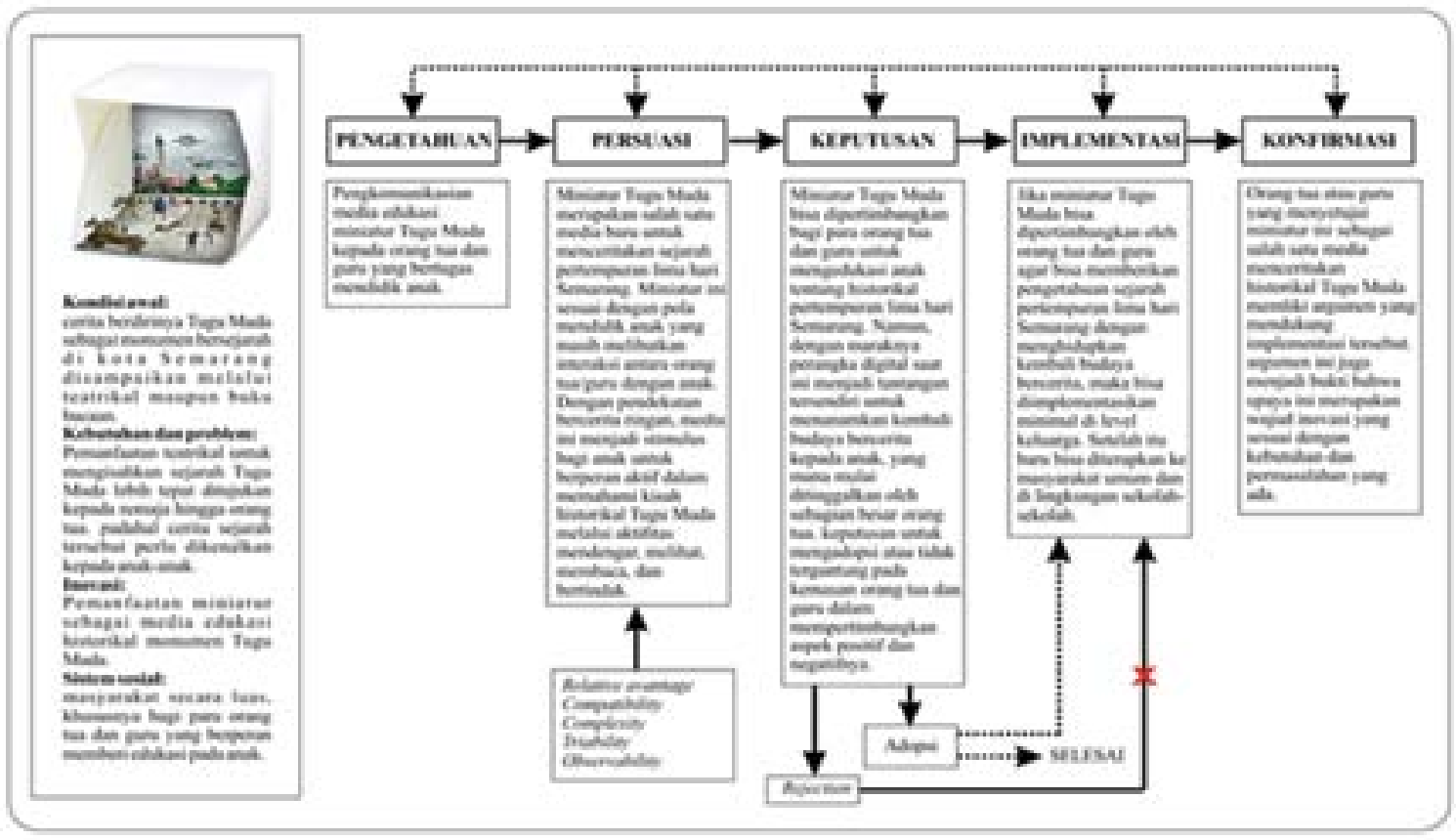


Adaptasi Difusi-Inovasi pada bagan di atas digunakan untuk mengusulkan miniatur Tugu Muda sebagai media atau cara baru dalam mengedukasi anak-anak tentang sejarah pertempuran lima hari Semarang. Pemilihan miniatur sebagai media baru ini dilatarbelakangi belum adanya cara yang tepat untuk mengenalkan historikal monumen Tugu Muda kepada anak, yang juga diperparah dengan mulai memudarnya budaya bercerita dari orang tua kepada anak. Hal ini mendorong pengusulan media baru yang bisa menumbuhkan kembali budaya bercerita serta mengurangi kecanduan perangkat smartphone sebagaimana telah terjadi akhirakhir ini. Dalam konteks ini, miniatur menjadi media baru yang ditawarkan kepada orang tua dan guru untuk lebih mendekatkan anak dengan sejarah kota Semarang.

Pemanfaatan miniatur ini perlu dikomunikasikan kepada masyarakat luas agar dipahami terlebih dahulu letak adaptasi difusi-inovasinya. Hal ini didasarkan pada gaya beljar anak yang mengkolaborasikan aktifitas mendengar, melihat, membaca, serta bertindak, sehingga anak lebih mudah menyerap informasi yang diterima. Pemilihan media game didasarkan pada pertimbangan bahwa anak hidup di era digital, sehingga membutuhkan media yang edukatif dan menyenangkan bagi anak.

Pemanfaatan media ini perlu mendapat respon dari orang tua maupun guru dengan mempertimbangkan sisi kemanfaataan yang bisa diperoleh. Dengan semakin sibuknya orang tua khususnya yang fokus pada pekerjaan (karir), media ini bisa menjadi kurang optimal karena membutuhkan waktu dan upaya yang besar. Kesiapan orang tua maupun guru mempengaruhi apakah media ini bisa langsugn diterima, bisa dipertimbangkan, atau justru ditolak sama sekali. Keputusan ini mempengaruhi langkah berikutnya.

Orang tua dan guru yang setuju memanfaatkan miniatur sebagai media edukasi monumen historikal Tugu Muda yang mengisahkan pertempuran lima hari Semarang berpeluang menerapkan cara ini pertama kali di lingkungan terdekatnya, yaitu keluarga. Melalui media ini, orang tua maupun guru memiliki peran vital yaitu mendampingi dan membangun interaksi dengan anak dalam menceritakan sejarah Tugu Muda secara interaktif, komunikatif, serta kreatif. Dalam tahap konfirmasi, orang tua maupun guru yang setuju memiliki argumen yang mendukung, sehingga bisa disebarluaskan kepada masyarakat lain agar menerapkan cara ini agar tercipta suasana belajar yang efektif dan menyenangkan bagi anak-anak.

\section{Simpulan dan Saran}

Belum adanya cara dan media yang tepat untuk mengenalkan sejarah pertempuran lima hari Semarang yang ditandai berdirinya monumen Tugu Muda mendorong peneliti mencari alternatif yang memungkinkan. Aspek utama yang menjadi perhatian yaitu membangun komunikasi antara orang tua atau guru kepada anak melalui cara yang menyenangkan. Gaya belajar anak yang terdiri dari empat gaya yakni mendengar, melihat, membaca, dan bertindak perlu dikemas melalui cara dan media yang tepat, salah satunya yaitu miniatur. Miniatur 
diajukan sebagai media baru yang dikembangkan dengan metode Design Thinking.

Pemanfaatan miniatur sebagai media baru yang menghidupkan kembali budaya bercerita orang tua atau guru kepada anak dikonsep sesuai dengan tahapan dalam Teori Difusi-Inovasi, yang dimulai dari Pengetahuan hingga Konfirmasi. Konsep ini diperlukan untuk mencari kemungkinan-kemungkinan yang akan muncul seiring digunakannya media atau cara baru, dengan mempertimbangkan kesiapan pihak-pihak yang terlibat di dalamnya. Dengan menghidupkan kembali budaya bercerita, hubungan antara orang tua atau guru kepada anak akan lebih dekat sehingga anak merasa nyaman dan mudah dalam menyerap informasi yang disampaikan.

\section{Daftar Pustaka}

Antoni. (2004). Riuhnya Persimpangan Itu: Profil dan Pemikiran Para Penggagas Kajian IImu Komunikasi. Solo: Tiga Serangkai

Daryanto. (2014). Teori Komunikasi. Malang: Gunung Samudera

Haryadi, Toto. 2017. Adaptasi Teori Difusi-Inovasi dalam Game "Yuk Benahi" dengan Pendekatan Komunikasi SMCR. Jurnal Audiens, Vol 1[1], h 1-14. Semarang: Universitas Dian Nuswantoro

Herawati, Elly. 2016. Relief Tugu Muda Mengisahkan Pertempuran Lima Hari Semarang. Diakses dari: https://www.viva.co.id/vbuzz/833259-relief-tugu-muda-mengisahkanpertempuran-lima-hari-semarang, pada: Maret 2019

Komandoko, Gamal. 2010. Ensiklopedia Pelajar dan Umum: Buku Serba Tahu Tentang Pengetahuan Umum Indonesia dan Dunia. Yogyakarta: Pustaka Widyatama

Radianto, W E D, dkk. Generasi Entrepreneur: Anda Bisa Menciptakan Entrepreneur. Yogyakarta: ANDI

Ramdhan, H. E. 2016. Startupreneur: Menjadi Entrepreneur Startup. Jakarta: Penebar Plus

Rogers, E. M. (1983). Diffusion of Innovation. New York: The Free Press

Salam, Nur. 2018. Peringatan Pertempuran Lima Hari, Hendi: Hargai kemerdekaan. Diakses dari: https://semarang.merdeka.com/kabar-semarang/peringatan-pertempuran-limahari-hendi-hargai-kemerdekaan-181014c.html, pada: Maret 2019

Santoso, W. M. (2014). Ilmu Sosial di Indonesia: Perkembangan dan Tantangan. Jakarta: Yayasan Pustaka Obor Indonesia

Utami, Mudjibah. 2015. Cerita Perang Kemerdekaan Indonesia: Kisah Heroik Melawan Penjajah Membangkitkan Semangat Nasionalisme. Jakarta: Wahyumedia

Zaman, Saeful dan Libertina, Aundriani. 2012. Membuat Anak Rajin Belajar Itu Gampang. Jakarta: Visimedia 